\title{
Application of Information Systems for Assessing the Level of Social Development to Optimize the Transition Process to the Digital Economy
}

\author{
Vinogradova N.A. ${ }^{1,}$ Matveev V.V. ${ }^{2}$
}

\author{
${ }^{1}$ Mtsensk branch of the Oryol State University. I.S. Turgenev, Mtsensk, Russia, \\ ${ }^{2}$ Oryol branch of the Financial University under the Government of the Russian Federation, Oryol, Russia \\ *Corresponding author. Email:vna-06@yandex.ru
}

\begin{abstract}
The article considers the need and the possibility of using a system of indicators to assess the final results of the implementation of the Digital Economy of the Russian Federation Program. The digital economy is largely virtual, intangible. But it is impossible without communication with the material world. Therefore, its effectiveness and efficiency are primarily expressed in the social development of the regions, the growth of the quality of life of the population. Obviously, the management process should be based on reliable data on the progress achieved, or existing problems in various areas of the Program. These reliable data can be obtained through the use of a system of estimated indicators for monitoring the final results of the sold estates and their impact on the efficiency of social development of the country and its regions.
\end{abstract}

Keywords: digital economy, social development, efficiency, indicators

\section{INTRODUCTION}

Modern state policy is increasingly oriented towards such goals as quality of life, human well-being, and sustainable development. The Digital Economy of the Russian Federation Program adopted in 2017 (hereinafter referred to as the Program) provides for the creation of a stable and secure information and telecommunication infrastructure for high-speed transmission, processing and storage of large amounts of data, accessible to all organizations and households. The goals of the program are:

- creation of conditions for the development of a knowledge society in the Russian Federation;

- improving the well-being and quality of life of citizens by increasing the availability and quality of goods and services produced in the digital economy using modern digital technologies;

- raising awareness and digital literacy of the population;

- improving the accessibility and quality of public services for citizens;

- ensuring information security both within the country and abroad.

Thus, this program will improve the quality of life, accelerate social development on a sustainable and longterm basis.

The digital economy is largely virtual, intangible. But it is impossible without communication with the material world. Therefore, its effectiveness and efficiency are primarily expressed in the social development of the regions, the growth of the quality of life of the population.

At all stages of the implementation of the Program, it is necessary to monitor its effectiveness and efficiency in the areas of development of the digital economy prescribed in the Program, namely:

- Normative regulation

- Digital infrastructure

- Technological groundwork

- Personnel and education

- Information security

The need to assess the results achieved, first of all, is determined by the need of the state management system and social development as a whole.

The Program proposes to monitor the effectiveness of the implemented areas of the digital economy according to an extensive system of indicators, allowing to assess the achievement of the goals and objectives of each of the areas of the Program.

However, the possibility of obtaining an integrated assessment of the impact of the Program's results on the effectiveness of social development, on changing the quality of life in the regions and the country as a whole is not provided, that is, it is not possible to assess the cumulative effect that society received from the implementation of this Program.

Obviously, the management process should be based on reliable data on the progress achieved or existing problems in various areas of the Program. 


\section{METHODS OF RESEARCH}

The need to evaluate the results of social development, first of all, is determined by the need for a system of managing social development. Obviously, the process of managing social development should be based on reliable data on the progress achieved or existing problems in various areas of development. Such information is extremely important for the following reasons.

Firstly, the assessment of development results allows us to identify the most problematic areas and determine development priorities. For example, it is known that for developing countries economic development is usually a priority, which can reduce poverty, increase employment, and generally solve many social problems. However, for many developed countries, environmental sustainability has long been a priority. Hence the emergence of a "green economy" and international initiatives in the field of global ecology from the club of developed countries goes. Thus, we can say that development problems, as well as development priorities, are different for developing and developed countries.

Secondly, the assessment of development results in time or space provides important information on the effectiveness of the measures taken, the policy of social development as a whole. Comparison of development results by country or region allows us to highlight the best practices for solving various development problems that can subsequently be applied by other countries or regions.

In the social development management system, the evaluation of development results is a subsystem at the input and output of the management system. In other words, management of social development should begin with setting goals and evaluating development results at the initial time and should end with evaluating the results achieved. Let us consider for this the stages of public development management.

Thus, monitoring the achievement of the main goal of the Program, managing this process, evaluating the effectiveness of the tools used require the development and application of relevant criteria and indicators - indicators of sustainable development.

As we revealed earlier in the work of Vinogradova N.A. "Practical experience in the field of statistics indicates that the construction of indicator systems should be based on indepth knowledge and theoretical analysis of the processes under study. Based on the task and a detailed analysis of the processes, the properties and features of the studied phenomena are established, each of which is expressed by one or more features. By any sign, it is possible to calculate not one, but several indicators; and the totality of all indicators selected in the process of such complex work will make up their desired system. We emphasize that the excessive completeness of the system, as well as the detailing of individual indicators, are very often unnecessary. Only the most important, most needed indicators should be included in the system" [1, p.23] In connection with the development of the digital economy, the intensification of globalization on this basis, all economic activity in the country is affected by both external and internal factors. All this cannot but cause the need for a significant change in the system of indicators for assessing the level of social development in order to assess the ongoing changes in the country and its regions.

\section{RESEARCH RESULTS}

Based on the foregoing, it is possible to propose a typical scheme for assessing the final results of sold estates and their impact on the efficiency of social development of the country and its regions (Figure 1).

Considering the problems of assessing and measuring the results of social development, first of all, the following should be highlighted:

- multidimensionality of development;

- differences in the characteristics of development at different levels of society;

- $\quad$ subjectivity of development results;

- large time lags between the start of the measurement, the receipt of the measurement results and the response of the authorities;

- the choice between a scorecard and an integral indicator.

Let us consider these problems in more detail.

\subsection{Problem 1: Multidimensionality of development.}

Social development is an unusually diverse process, since in a broad sense it includes all aspects of human life. Moreover, it becomes difficult to evaluate the results of social development, since one has to deal with very different processes in terms of content and nature. It should be admitted that at present, with the achieved level of development of statistical science, practically no sphere of social development is left without the attention of scientists, and the databases contain a huge variety of diverse indicators. Mankind has learned to collect information about its development, but we can't always discern the main trends in this set.

The task of measuring social development consists precisely in highlighting the main problems and trends that could most fully (although obviously, not completely) characterize its development in the multidimensional movement of society from the past to the future. That is, the main components of development should be highlighted, for example, the economy, social sphere, environment, etc., as well as the "markers" of development, that is, indicators by which we can judge the results of development. 


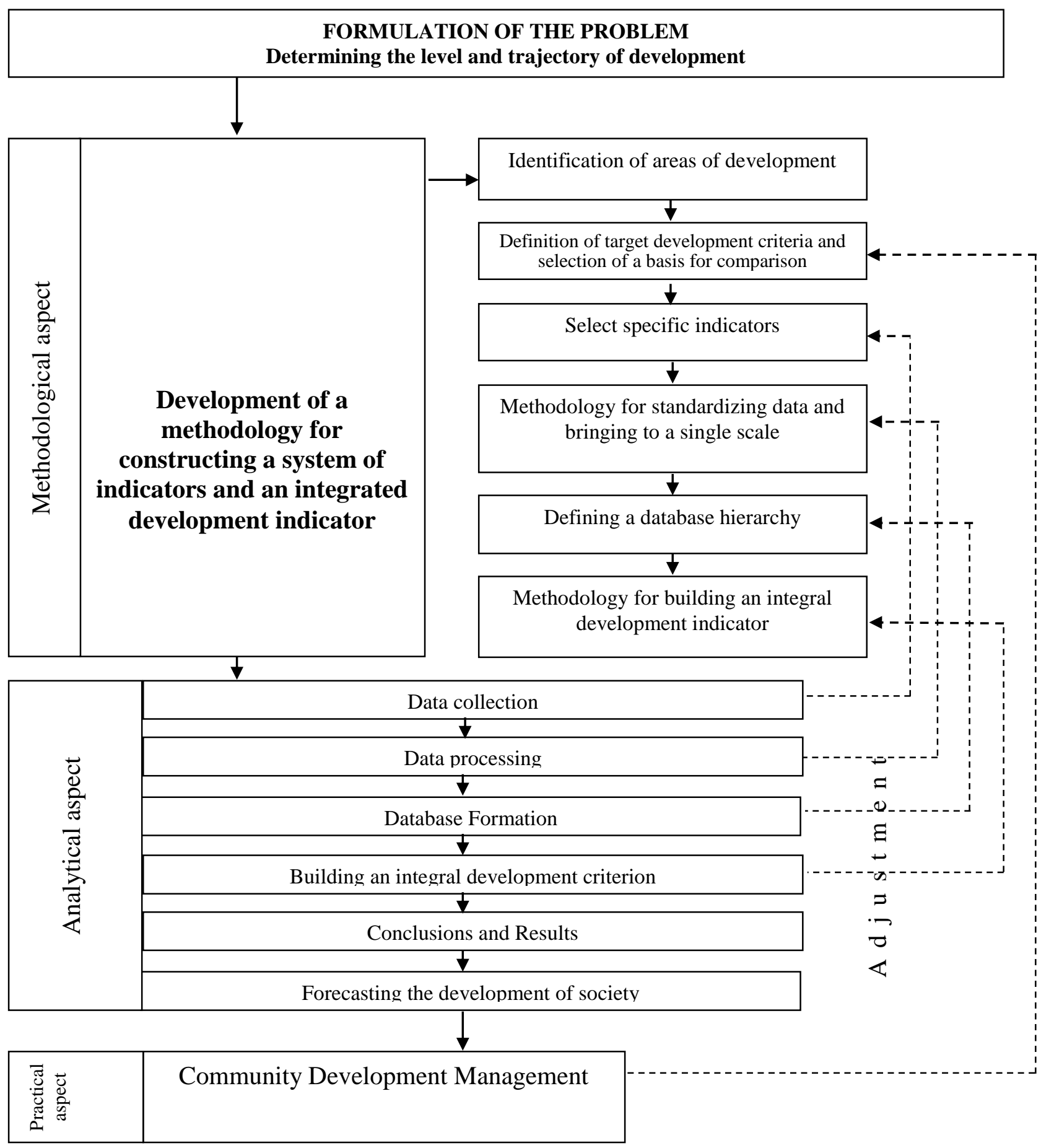

Figure 1 Algorithm for assessing the dynamics of end results and the effectiveness of social development

The selection of development components should be based on the goal-setting, which was discussed above. Society should agree on the importance and materiality of certain aspects of human development. For example, one could imagine that for some religious or other reasons, people do not consider longevity as one of the components of their well-being. Then, obviously, the development goals would shift to other aspects. In fact, this happens inside society, only in a less pronounced form, when different people have their own ideas about the well-being and quality of life. Thus, the multidimensionality of development is closely related to the subjectivity of development. The identification of the main components of development can 
be carried out only on the basis of common vectors of group interests.

Multidimensionality also means that the results of evaluations of various aspects of development cannot always be combined into a general assessment. That is, to say which country is more developed, in fact, is not possible, since the "undeveloped - developed" scale is a one-dimensional and incorrect idea of development. This makes it difficult to compare some countries with others, but this does not mean that such comparisons are not needed. Therefore, despite the multidimensionality of development, methods are needed to evaluate the development of some regions relative to others.

\subsection{Problem 2: Differences in the characteristics of development at different levels of society.}

As already mentioned, for most people on the planet, important components of quality of life are health, education, economic well-being and the environment. Consider them and show that there is a relationship between them, more closely than it seems. We will do this using the example of countries of the world and regions of Russia.

To assess the results of development at the country level, we will choose indicators from various spheres of public life (Table 1).
We show the relationship between these indicators for spatial data samples. Table 2 shows the matrix of correlation coefficients for the above indicators

Table 1 Indicators for assessing the relationship between the development of various fields by country

\begin{tabular}{|c|c|c|}
\hline Sphere & Index & Source \\
\hline Economic & $\begin{array}{l}\text { Parity GDP } \\
\text { per capita, } \\
\text { USD }\end{array}$ & UN - http://data.un.org \\
\hline \multirow[t]{4}{*}{ Social } & $\begin{array}{l}\text { Life } \\
\text { expectancy } \\
\text { years }\end{array}$ & UN - http://data.un.org \\
\hline & $\begin{array}{l}\text { Level of } \\
\text { education, } \\
\text { years }\end{array}$ & UN - http://data.un.org \\
\hline & $\begin{array}{l}\text { Differentiation } \\
\text { of income, } \\
\text { Gini }\end{array}$ & $\begin{array}{l}\text { World Bank - } \\
\text { http://databank.worldb } \\
\text { ank.org }\end{array}$ \\
\hline & Crime level & $\begin{array}{l}\text { Numbeo Base - } \\
\text { http://www.numbeo.co } \\
\text { m/crime/ }\end{array}$ \\
\hline $\begin{array}{l}\text { Environmen } \\
\text { tal }\end{array}$ & $\begin{array}{l}\text { Environmental } \\
\text { Performance } \\
\text { Index }\end{array}$ & $\begin{array}{l}\text { Yale university. } \\
\text { Environmental } \\
\text { Performance Index } \\
\text { Website - } \\
\text { http://www.epi.yale.ed } \\
\text { u }\end{array}$ \\
\hline
\end{tabular}

Table 2 Matrix of paired correlation coefficients between the development indicators of various spheres of public life in the countries of the world

\begin{tabular}{|c|c|c|c|c|c|}
\hline & $G D P(d)$ & Life span & Education & Gini & Crime \\
\hline Life span & 0.608 & 1000 & & & \\
\hline Education & 0.607 & 0.782 & 1000 & & \\
\hline Gini & -0.343 & -0.364 & -0.376 & 1000 & \\
\hline Crime & -0.497 & -0.456 & $-0,409$ & 0.452 & 1000 \\
\hline Ecology & 0.717 & 0.791 & 0.847 & -0.395 & -0.486 \\
\hline
\end{tabular}

Consider the results of correlation analysis. Cells are marked in gray, the correlation coefficients in which fit into the general logic of the relationship of the studied indicators. For example, the level of average per capita GDP positively correlates with life expectancy, educational attainment, environmental success, and inversely correlates with income inequality and crime rates. Also, life expectancy correlates positively with the level of education and the environment, and negatively correlates with the level of inequality and crime. The level of education is negatively related to the level of inequality and crime and positively related to the environmental situation. Finally, the level of inequality is positively related to the level of crime, and environmental success is negatively related to the level of inequality and crime.

Thus, all considered indicators are interconnected with each other according to generally accepted logic. Moreover, the degree of relationship is quite close and statistically significant.

Now we will consider the same indicators for the regions of Russia, with the only difference being that the indicator reflecting the ecological environment is not included in the analysis. Firstly, there is no index similar to the Environmental Performance Index for the Russian regions. 
Secondly, the use of any one indicator of the size of pollutant emissions or biodiversity will not reflect the whole situation in the environment of the region. Therefore, we abandoned the indicator characterizing the ecological environment in this simplified analysis (Table 3). The results of the correlation analysis by region are presented in the following Table 4.

Table 3 Indicators for assessing the relationship between the development of various fields by region [11]

\begin{tabular}{|l|l|}
\hline \multicolumn{1}{|c|}{ Sphere } & Index \\
\hline Economic & GRP per capita adjusted for purchasing power coefficient \\
\hline Social & Life expectancy years \\
\cline { 2 - 3 } & The proportion of children studying in educational institutions \\
\cline { 2 - 3 } & Differentiation of income, Gini \\
\cline { 2 - 3 } & Crime rate (Number of registered crimes per 100 thousand people) \\
\hline
\end{tabular}

Table 4 Matrix of paired correlation coefficients between development indicators of various spheres of public life in the regions of Russia

\begin{tabular}{|c|c|c|c|c|}
\hline & GRP $(d)$ & Life span & Education & Gini \\
\hline Life span & $\mathbf{- 0 . 1 8 8}$ & 1000 & & \\
\hline Education & 0.305 & $\mathbf{- 0 . 7 2 5}$ & 1000 & \\
\hline Gini & $\mathbf{0 . 5 2 9}$ & $\mathbf{0 . 1 2 7}$ & $\mathbf{0 . 0 3 9}$ & 1000 \\
\hline Crime level & $\mathbf{0 . 3 0 8}$ & -0.648 & $\mathbf{0 . 6 4 3}$ & 0.140 \\
\hline
\end{tabular}

The gray color in this table also indicates cells with correlation coefficients that correspond to the standard explanation. Moreover, the relationship between income inequality and crime is not statistically significant. However, it is clear that most of the correlation coefficients are contrary to sound logic. For example, life expectancy is negatively correlated with the level of education, and the level of education is positively correlated with the level of crime, etc. These coefficients in the table are marked in bold.

Of course, there is an explanation for such illogical relationships. For example, higher crime is observed in more economically developed regions, since most crimes are, for example, petty thefts. Hence the close relationship of the crime rate with the level of education. Perhaps similar explanations can be found for other "illogical" relationships. However, this analysis shows that at the level of the

Table 5 Comparison of variation coefficients for the studied indicators in country and regional samples

\begin{tabular}{|l|c|c|c|c|c|}
\hline & GDP / GRP & Life span & Education & Gini & Crime \\
\hline Countries & 1.106 & 0.125 & 0.270 & 0.245 & 0.358 \\
\hline Regions & 0.666 & 0.037 & 0.060 & 0.055 & 0.348 \\
\hline
\end{tabular}

As you can see, the variation in GDP indicators (for GRP regions) is much higher in the sample of countries than in the regional sample. The same applies to other indicators. The exception, perhaps, is the crime rate, where the difference in variation between regions and between countries is insignificant. country's regions, albeit as large and geographically diverse as Russia, the results of social development in various fields are not as closely interconnected as at the intercountry level. In other words, "logical" relationships are built only when studying macro objects, when we look at processes with a large scale. Having descended to a lower spatial level, these relationships may be lost or even turn out to be negative. The reason for this, most likely, is a smaller variation of signs-phenomena in more homogeneous groupings of regions. That is, the differentiation in intercountry development is much greater than in interregional.

We show this using the coefficient of variation, which is the ratio of the standard deviation to the average value of the characteristic in the sample (Table 5).

Thus, an important conclusion can be made that at the regional level, the study of socio-economic processes, social development as a whole is difficult due to the greater homogeneity, that is, the homogeneity of the regions. This prevents the use of standard methods of correlation and regression analysis. In addition, the sample by region is 
much smaller than by country. It also affects the quality of the identified relationships between indicators.

\subsection{Problem 3: Subjectivity of development.}

For a long time, objective indicators like gross domestic product, national income, etc. were considered as the main indicators of well-being and assessments of social development even carried out on the basis of them. However, in recent years there have been major changes in understanding welfare. In particular, it is recognized that it should include subjective characteristics, such as satisfaction with life, happiness, etc. The relationship between incomes as objective factors of well-being and level of happiness is especially widely studied. The socalled "economy of happiness" appeared. In particular, the American scientist R. Easterlin revealed that "the level of wealth of a country does not affect the proportion of people who consider themselves happy". [9, p.29]

This pattern was called the Easterlin Paradox. People felt happier, not because of "absolute wealth", but because they had "relative wealth". That is, people prefer to be more relatively rich in an absolutely poor society than to be richer in absolute terms, but poor relative to other people. The research of Nobel laureates in economics D. Kahneman and A. Deaton should also be noted, which showed that "there is a threshold level of income above which the level of happiness becomes insensitive to income". [8, p. 33] A more important factor of welfare according to A. Deaton is "equality in society". [2, p.15]

The subjectivity of development also means that for each person, as well as for each country, there is a subjective understanding of well-being. For poor people or entire countries, even small economic benefits will bring a high increase in subjective well-being and increase life expectancy. Therefore, development goals usually lie on the economic plane - reducing poverty, hunger, providing employment, raising wages, etc. However, for rich people or developed countries, the growth of well-being is not so closely connected with economic factors, and priorities are formulated already in the plane of sustainable development, focusing on the environment, social problems, etc.

The subjectivity of development is observed not only on a spatial scale. In the time perspective, development priorities also change, as does the subjective assessment of welfare. Obviously, people who lived two or three centuries ago were deprived of many of the benefits that people have now. However, they were hardly less happy than modern people, that is, their subjective well-being was perhaps as high as that of the people living now. But many modern countries can be compared among themselves in exactly this way through a lag in economic development, expressed in years. That is, poorer countries are countries that are a little in the past in terms of social progress. But this does not mean at all that people living in such countries are more unhappy than people living in advanced countries.

The presence of subjectivity in understanding well-being and development goals makes it difficult to evaluate the results of social development, since it is difficult to choose a single measure for different people, countries, etc. In this regard, it would seem that there is no need to clutter up the rating system with numerous indicators that may turn out to be absolutely unimportant, for example, for poor countries or regions. However, consideration should be given to changing future development priorities. What is relevant today in developed countries will be relevant in developing countries tomorrow. If today for the developing regions, especially the industrially undeveloped, environmental issues are not as acute as for developed countries, then in the future this state of affairs may change. Therefore, a rating system should be formed taking into account future priorities of social development.

\subsection{Problem 4: Large time lags between the start of the measurement, the receipt of the measurement results and the response of the authorities.}

The study of the results of social development begins with the collection of statistical information. However, often, there are significant time lags between the beginning of the collection and processing of data, the receipt of measurement results and the response of authorities to this data.

For example, if we look at international statistics, then the time lags are the longest and sometimes reach several years. This is explained by the length of the stages of data transmission and processing by national statistical services to international statistical bodies. For example, the Human Development Report 2015, published at the end of 2015, includes data for 2014. However, most international statistics have a time lag of 2-3 years. National statistics also come out with some time lag, albeit less than international statistics.

All this does not contribute to improving the management of social development at the international, national or regional levels.

The Millennium Development Goals 2015 Report states that real-time information is needed to ensure preparedness to respond to economic, political, environmental and epidemiological crises. It is also recognized that most developmental data is delayed by two to three years. It is proposed to use new technologies and a number of examples are given when this was done. In particular, to facilitate the collection and exchange of real-time Ebola outbreak information, UNICEF and its partners used short text messaging (SMS) technology. [6, p. 9]

Nevertheless, it seems that on a global scale, the collection and processing of data in the "real time" is not yet possible. And to solve this problem can take more than one decade. In this regard, management decisions should be aimed at the future. That is, it is necessary to analyze the available retrospective data, to make forecasts of changes in the main indicators of social development for the future. And already based on this to develop management decisions. Such a model is called prognostic management of social development. 
Each of the simple indicators can have a certain value in assessing development. However, these traditional indicators do not reflect the numerous social and economic processes and development phenomena in their relationship.

\section{DISCUSSION OF RESULTS}

Thus, the development of the country is a multidimensional and multi-aspect process that can be considered from the point of view of various socio-cultural, economic, political and environmental goals and results.

As shown by a previous of study Vinogradova N.A. "Despite such a wide range of private indicators of development, the question of the integral indicator remains open. Private indicators usually characterize a certain area of development. It is even possible to create a certain amount on their basis, but if it is possible to derive an integral characteristic that takes into account the whole variety of development aspects, remains a debatable question.

There are two points of view on this question. According to the first, it is necessary to search or create criteria that are identically regarded in all countries. According to the second, the uniqueness of any country does not allow this. For example, what is highly valued in a developed country will not always be appreciated in a developing country, and vice versa. For example, there are various organizations that conduct and publish surveys characterizing the relationship between people, between people and the state." [1, p.24]

The data of international studies on the level of public confidence in the government show that "the highest level of trust in Norway, Sweden and China is $65 \%, 60 \%, 52 \%$, respectively, and the lowest (3\%) is in Brazil." [7, p. 66]

There are also a number of indices characterizing the climatic or social conditions of living in a particular country. But all these characteristics, due to at least the differences in the people of these countries, lead to too much distortion. Not to mention economic indicators.

In addition, there is an opinion about the methodological impossibility of obtaining integral indices of the highest level. For example, in the works of Mazurov Yu.L. and Tikunov V.S. it is argued that "since absolute stability, identical stability, constancy of the states of the social components of the picture of the world, etc., cannot be in principle, then there cannot be universal indicators of sustainability of development to the same extent". [4, p. 65] This is confirmed by an experiment to assess social sustainability. So, in the work I. N. Rubanov and V. S. Tikunov assert that "when calculating the integral index, the qualitatively opposite values of demographic indicators and indicators of population welfare mutually level each other; under such conditions, it is inappropriate to talk about leadership and ranking the regions according to the degree of social stability, because in determining leaders, the subjective opinion of the researcher acquires key importance, namely, which of the groups of indicators he attaches more weight to. For this reason, the authors considered it inappropriate to calculate the integral index of social sustainability and decided to confine themselves to calculating three particular indices characterizing the main components of social sustainability".[5, p. 42]

Thus, "the lack of a universally recognized integral indicator (the HDI can only partially claim this role) does not allow us to give a generalized assessment of the state of a country or region, which, therefore, complicates a comprehensive study of their socio-economic development." [1, p. 23]

Therefore, in recent years more and more attempts have been made towards combining the assessment of the social, economic and environmental aspects of the development of society in the form of creating integrated development indicators. Various international organizations and individual countries are actively developing development criteria and indicators, which often contain a very complex system of indicators. Attempts to create integrated development indicators are most fully implemented in the development of the UN and the World Bank. These international organizations have proposed methods to enable the inclusion of a wide variety of factors in national accounts, in indicators of national wealth, social, demographic and political estimates. [10]

Obviously, the real development of human society and its activities is much more complicated than that which can reflect any of the integral indicators. The most extensive range of statistical data and works of experts, private and summary indicators will not reveal all the roots, aspects and levels of development. However, such indicators make it possible to quickly and fairly accurately reflect the trajectory of the country's development in a multidimensional space defined by the target guidelines of individual areas of development of society.

\section{CONCLUSION}

Thus, "the integral criterion of development is an integral part of the system of indicators for monitoring the corresponding processes, since it allows seeing how the development of an object changes with a change in one or another of the initial factors. The integral criterion allows us to judge the degree of development of the object of observation, and its dynamics - about the trajectory or development efficiency. However, due to methodological and statistical problems (data collection, their reliability, calculations), an integral indicator universally recognized in the world that covers all aspects of social development has not yet been created. However, research in this area is ongoing." [1, p.25]

As can be concluded from the foregoing, evaluating the development, we, one way or another, resort to a comprehensive assessment that uses a number of initial indicators. Moreover, according to V.N. Leksin N. and Shvetsova A.N. "With appropriate assessments, one should always remember that development is not an analogue of the process of mechanical growth or structural complications, but the desire for structural balance, completion of missing links, elimination of the 
[10] Fischer S. The role of macroeconomic factors in growth // Journal of monetary economics. 1993. Vol. 32. R. $485-512$.

[11] Federal'naya sluzhba gosudarstvennoy statistiki. Promyshlennoye proizvodstvo. - URL: http://gks.ru/wps/wcm/connect/rosstat/rosstatsite/main/e nterprise/industrial/
[1] Vinogradova, N.A Napravleniya ispol'zovaniya sistemy statisticheskikh pokazateley $\mathrm{V}$ otsenke effektivnosti obshchestvennogo razvitiya / N.A. Vinogradova // Ekonomika i predprinimatel'stvo.2014.-№11 (52).--s.22-25.

[2] Diton A. Velikiy pobeg. - M.: 2016. S. 34.

[3] Leksin V.N., Shvetsov A.N. Gosudarstvo i regiony. Teoriya i praktika gosudarstvennogo regulirovaniya territorial'nogo razvitiya. 3-ye izd. M.: URSS, 2000. 368 s.

[4] Mazurov YU.L., Tikunov V.S. Izmereniye ustoychivosti razvitiya sotsiuma, ot interpretatsii $\mathrm{k}$ raschetam // Materialy mezhdunarodnoy konferentsii «Ustoychivoye razvitiye territoriy: teoriya GIS i prakticheskiy opyt», Inter-Karto/InterGIS 11, Stavropol', Dombay, Budapesht, 2005. S.21-36.

[5] Rubanov I.N., Tikunov V.S. Metodologiya otsenki ekologicheskoy sostavlyayushchey ustoychivogo razvitiya i sostoyaniya okruzhayushchey sredy v rossiyskikh usloviyakh// Materialy mezhdunarodnoy konferentsii «Ustoychivoye razvitiye territoriy: teoriya GIS i prakticheskiy opyt», Inter-Karto/InterGIS 11, Stavropol', Dombay, Budapesht, 2005. S.206-214.

[6] Tseli razvitiya tysyacheletiya: doklad za 2015 god / Organizatsiya Ob"yedinennykh Natsiy// http://www.un.org/ru/millenniumgoals/mdgreport2015. pdf

[7] Caring for the future: making the next decades provide a life worth living. Report of the independent commission on population and quality of life. New York: Oxford Iniversity Press, 1999.

[8] Diamond, Dan. https://www.forbes.com/sites/dandiamond/2015/10/12/a ngus-deaton-who-just-won-nobel-prize-thinks-a-75000salary-makes-you-perfectly-

happy/\#676fa58e7775Angus Deaton, Who Just Won Nobel Prize, Thinks A \$75,000 Salary Makes You Happy. Forbes.com

[9] Easterlin R.A. Building a Better Theory of WellBeing /ed. L.Bruni, P.L. Porta //Economics and happiness: framing the analysis. - New York:Oxford University Press Inc., 2005 - P. 29-30. 